\title{
Experimental Investigation of Scour Prediction Methods for Offshore Tripod and Hexapod Foundations
}

\author{
Xuan $\mathrm{Ni}^{1,2}$ and Leiping Xue ${ }^{2, *}$ \\ 1 Department of Engineering Mechanics, School of Naval Architecture, Ocean and Civil Engineering, \\ Shanghai Jiao Tong University, Shanghai 200240, China; nixuan1991@sjtu.edu.cn \\ 2 Key Laboratory of Hydrodynamics (Ministry of Education), School of Naval Architecture, \\ Ocean and Civil Engineering, Shanghai Jiao Tong University, Shanghai 200240, China \\ * Correspondence: lpxue@sjtu.edu.cn
}

Received: 27 September 2020; Accepted: 27 October 2020; Published: 30 October 2020

\begin{abstract}
Scour prediction is essential for the design of offshore foundations. Several methods have been proposed to predict the equilibrium scour depth for monopiles. By introducing an effective diameter, such methods could also be applied to predicting scour depth for pile groups. Yet, there are still difficulties in estimating the equilibrium scour depth of foundations in complex shapes, such as the tripod foundation. This study investigates the clear-water scour around the tripod and hexapod foundations through laboratory experiments, with uniform bed sediment and steady current. Here, the authors propose an approach to calculate the effective diameter for the tripod and hexapod models, which is similarly as for the pile groups. Three widely-used methods in predicting equilibrium scour depth have been evaluated, and the best method is recommended.
\end{abstract}

Keywords: scour prediction; experimental modeling; complex foundation; tripod foundation; hexapod foundation

\section{Introduction}

The pile-supported foundation is one of the commonly used foundations in the offshore environment, such as bridges, breakwaters, offshore wind turbines, and so forth. These foundation structures change the flow pattern in their vicinity, which may increase the local sediment mobility and result in scour around the structures. Scour may remarkably undermine the stability and usability of such foundation structures $[1,2]$. Thus, it is essential to accurately predict the sediment scour at piled foundations for their safe design.

Monopile is the most common supported foundation, and many studies have been done on scour around a single vertical cylinder. Raudkivi and Ettema [3] pointed out that the equilibrium scour depth around a vertical cylinder under clear-water condition is related to the following parameters: mean particle size of the bed sediment, distribution of particle size, and water depth relative to the pier diameter, and so forth. Through a series of experiments, Melville and Chiew [4] reported that the maximum scour depth depends on flow velocity, flow shallowness, sediment coarseness, and time factor. More studies to understand the scour around a circular cylinder are given by References [5-9].

In reality, supported foundations are often constructed in a group of piles based on mechanical and economic considerations. The structural complexity of the pile groups leads to more complicated flows around such structures than that around a single cylinder. According to Sumer and Fredsøe [5], due to the flow interference between adjacent piles, the scour around a pile group is significantly different from that around a single pile. Thus, it can be inferred that the results of scour around a single circular cylinder cannot be applied to pile groups directly. Both global and local scour at the 
pile groups have been studied by Sumer et al. [10], including different pile group configurations. Amini et al. [11] studied the scour around pile groups in steady currents experimentally, and the effect of pile spacing, pile group arrangement and submergence ratios was discussed. Liang et al. [12] conducted laboratory experiments of clear-water scour by considering different pile arrangements, including single pile, tandem piles side-by-side piles, and $3 \times 3$ pile groups. Through laboratory experiments, Qi et al. [13] investigated the scour around twin piles under combined current and wave conditions, and the effect of various gaps and alignments were discussed.

Various empirical formulas have been proposed to estimate the equilibrium scour depth for a single pile. For example, the HEC-18 (Hydraulic Engineering Circular No. 18) has been evolving progressively over the years, and it is currently a recommended method by the FHWA (Federal Highway Administration) [14]. The FDOT (Florida Department of Transportation) method is also widely used to calculate the scour depth at monopiles. By introducing an effective diameter, such methods could also be applied to predicting scour depth for pile groups. An approach to calculate the effective diameter for pile group foundations is proposed by Arneson et al. [14]. The effective diameter of the complex piers could be calculated by a procedure conducted by Coleman [15].

Recently, foundations with more complex shapes could be found in the offshore environment, such as the tripod and hexapod foundations used in the Shanghai Donghai Bridge Offshore Wind Farm and Jiangsu Rudong Offshore Wind Farm. Such foundations are constructed by combining vertical piles and lateral elements. Therefore, the associated sediment transport and scouring process around such foundations are also affected. Through laboratory experiments under different levels of scales, Stahlmann and Schlurmann [16] and Stahlmann and Schlurmann [17] investigated the scour around the tripod foundation under both regular and irregular wave conditions. The clear-water scour around a tripod foundation under steady current has been investigated through laboratory experiments by Yuan et al. [18].

Understanding of the scour around this type of complex foundations is limited by far, and there is still a lack of efficient methods to estimate scour depth around such foundations. In this work, we study the clear-water scour around pile groups and complex foundations, including triangular arrays of circular cylinders (TACC), hexagonal arrays of circular cylinders (HACC), tripod model and hexapod model. A series of experiments are conducted under steady current flow with non-cohesive sediment. Here, we propose an approach to calculate the effective diameter for the tripod and hexapod models, which is similarly as for the pile groups. Using the effective diameter, equilibrium scour depth is derived through extrapolation. Three widely-used methods on estimating equilibrium scour depth, which are the HEC-18 method [14], the Auckland method [15] and the FDOT method [19], are evaluated. Based on the present and previously published experimental data, the best method is recommended.

\section{Experimental Setup and Methods}

\subsection{Experiment Facilities}

The experiments are carried out in a rectangular brick-sided flume $(10 \mathrm{~m}$ long, $1 \mathrm{~m}$ wide, and $0.3 \mathrm{~m}$ deep) located at the Integrated Water Environment Management Laboratory, Hohai University. A flow straighter with a honeycomb pattern is equipped at the flume entrance to guarantee uniform and steady inlet flow conditions. At the downstream end of the flume, an adjustable tailgate weir controls the water level. The water that flows over the weir falls into an underground reservoir. Three pumps are used to elevate the water into the entrance of the flume. The sediment section is $4 \mathrm{~m}$ long, $1 \mathrm{~m}$ wide and $0.16 \mathrm{~m}$ thick, which is located at $6 \mathrm{~m}$ downstream of the inlet tank. A layout of the apparatus is illustrated in Figure 1. 


\section{Side View}
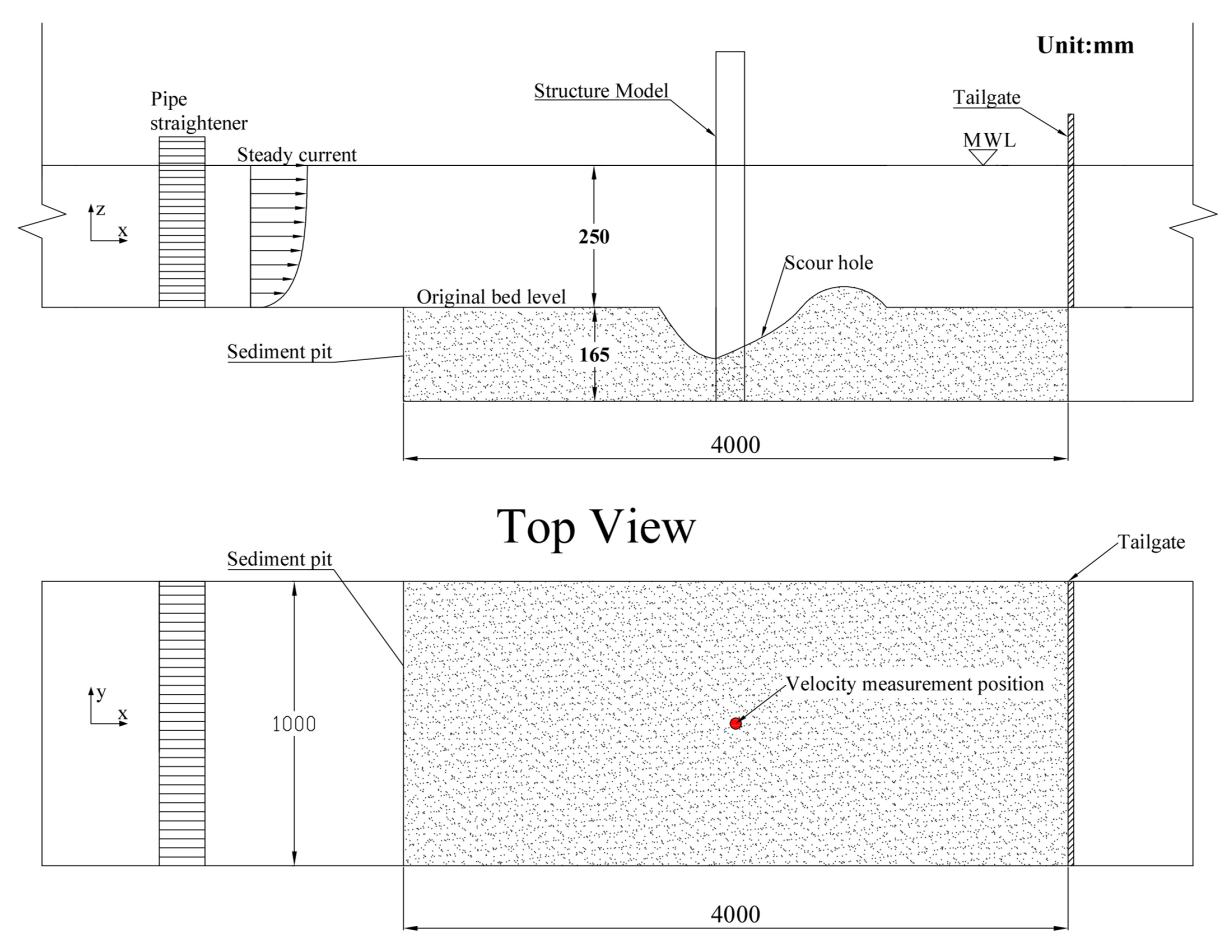

Figure 1. Schematic drawing of the experimental system. $(x, y, z)=$ longitudinal, transversal, and vertical directions, respectively. (Unit:mm).

The sediment section is filled with uniform quartz sand with specific gravity $s=2.65$, mean particle size $d_{50}=0.575 \mathrm{~mm}$ and the geometric standard deviation $\sigma_{g}=1.29$. As the sediments are practically uniform $\left(\sigma_{g}<1.5\right)$, the effect of sediment gradation on the scour depth in the present study is negligible [3]. The critical flow velocity of the sediment $\left(U_{c}\right)$ calculated by the equation of Schamovis given by Tang et al. [20] which is expressed as

$$
U_{c}=1.14 \sqrt{(s-1) g d_{50}}\left(\frac{h}{d_{50}}\right)^{\frac{1}{6}},
$$

where $g$ is the gravity acceleration and $h$ is the water depth. The calculated $U_{c}$ is $30.1 \mathrm{~cm} / \mathrm{s}$. Some preliminary runs are conducted with a visual inspection of the particle motion. The occasional single particle movement is observed when the mean flow velocity ranges from $30 \mathrm{~cm} / \mathrm{s}$ to $32 \mathrm{~cm} / \mathrm{s}$, which agrees with the calculated result.

\subsection{Experimental Conditions}

All the experiments are tested with constant water level $h=25 \mathrm{~cm}$. The present experiments are conducted in the clear-water regime. Two flow velocities are used here to investigate the effect of flow velocity on scour depth. As the maximum scour depth occurs at the threshold of sediment motion [21], one of the flow velocity is $U_{1} / U_{c}=0.93$, which is slightly below the critical condition. According to Sheppard [19], local scour around a circular cylinder is initiated when the approaching mean flow velocity exceeds $0.47 U_{c}$. Therefore, another flow velocity $U_{2}=0.74 U_{c}$, which is larger than $0.47 U_{c}$, is used here. The approaching flow velocity is measured by a Vectrino Acoustic Doppler Velocimeter (ADV), manufactured by Nortek, with a sampling of $200 \mathrm{~Hz}$ at a time window of $120 \mathrm{~s}$. The sampling volume of the ADV is located $5 \mathrm{~cm}$ below the transmitter probe. The ADV is used with a velocity range equal to $\pm 0.30 \mathrm{~m} / \mathrm{s}$ and a measured velocity accuracy of $\pm 1 \%$. The flow velocity is measured 
along with the water depth at the center of the sediment section without pile models, and the flow velocity profile is obtained. All the parameters are summarized in Table 1.

Table 1. Characteristics of flow and sediment.

\begin{tabular}{ccccccc}
\hline $\mathbf{h}(\mathbf{c m})$ & $\mathbf{U}_{c}(\mathbf{c m} / \mathbf{s})$ & $\mathbf{U}_{\mathbf{1}} / \mathbf{U}_{c}$ & $\mathbf{U}_{\mathbf{2}} / \mathbf{U}_{c}$ & $\mathbf{d}_{\mathbf{5 0}}(\mathbf{m m})$ & $\sigma_{g}$ & $\mathbf{s}$ \\
\hline 25 & 30.1 & 0.93 & 0.74 & 0.575 & 1.29 & 2.65 \\
\hline
\end{tabular}

Five pile-supported foundations are tested, including two complex foundation models (tripod model and hexapod model), two pile group models (triangular arrays of circular cylinders (TACC) and hexagonal arrays of circular cylinders (HACC)) and a monopile. The tripod and hexapod models are manufactured with a scale of 1:60. The geometry of all the models is shown in Figures 2-4. Different incident flow angles $(\alpha)$ are also considered, and $\alpha=0^{\circ}$ describes each model's alignment position with one leg facing the direction of incident flow attack. All the models are installed at the center of the sediment section, and all the legs of each model go to the recess bottom. Lança [22] observed that the contraction effect on the scour depth is absent when the obstruction ratio is less than $20 \%$. As the maximum obstruction ratio in the present study is $18 \%$, the contraction effect is ignored in the present research. Also, the minimum distance between the pile and the flume side boundary is larger than 7 times the pile's diameter. Therefore, the effect of the flume side boundary is neglected in this study.

a)

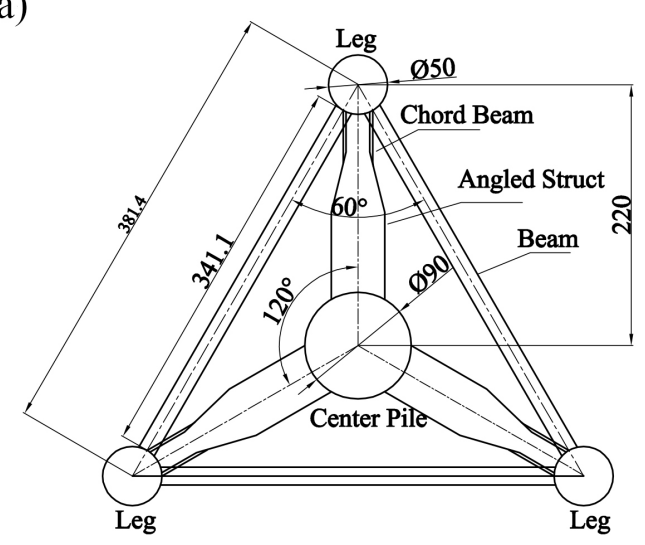

c)

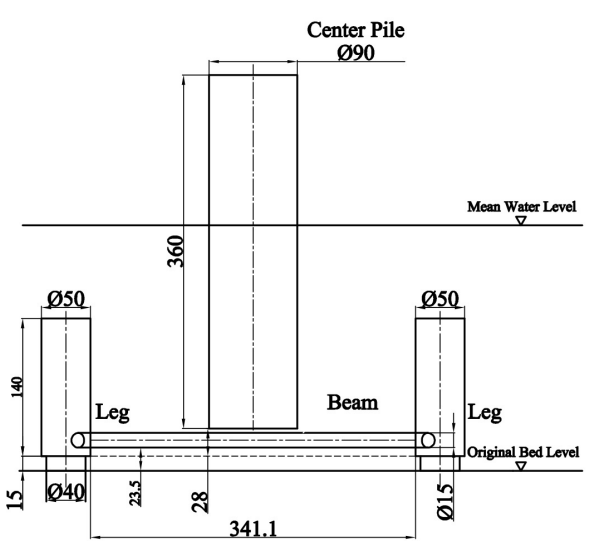

b)

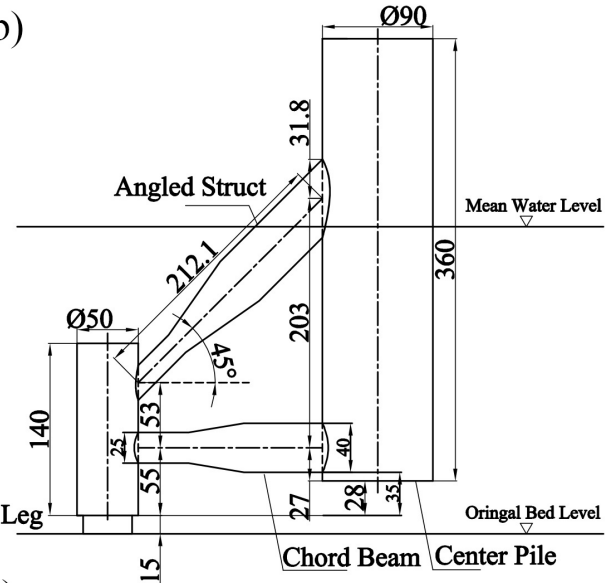

d)

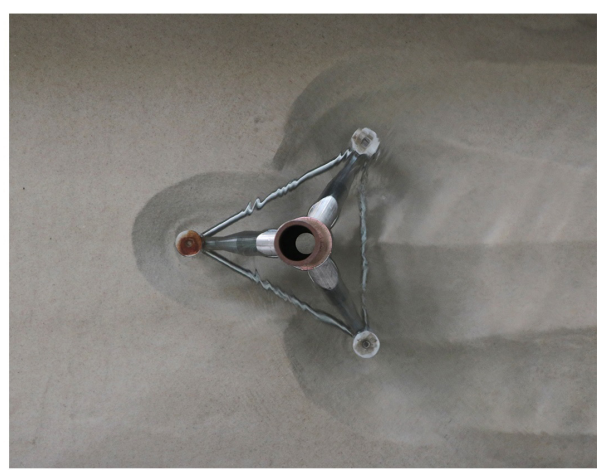

Figure 2. Sketches of the tripod model: (a) Top-view; (b) Side-view; (c) Front-view; (d) Photograph. (Unit: mm). 


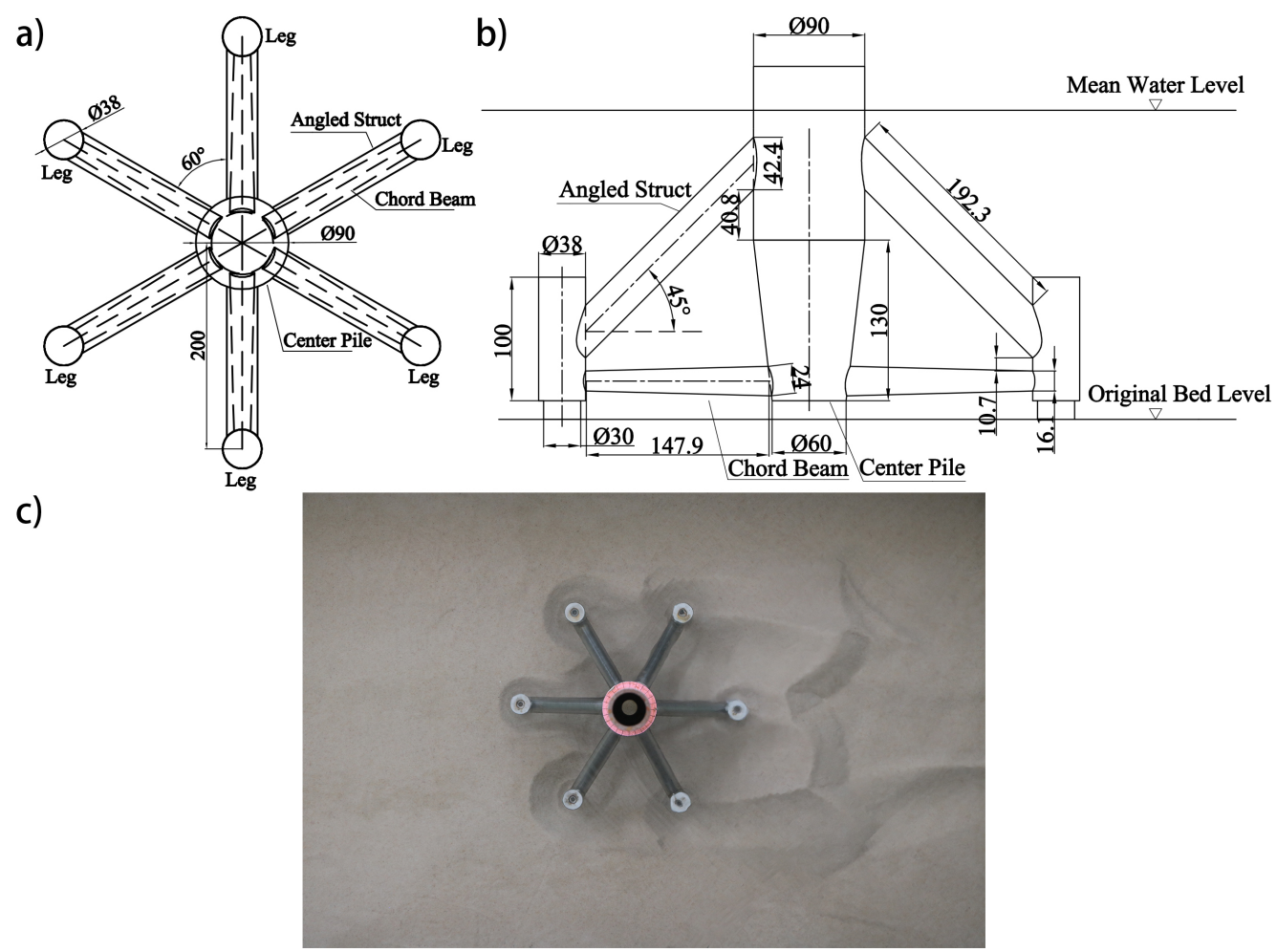

Figure 3. Sketches of the hexapod model: (a) Top-view; (b) Side-view; (c) Photograph. (Unit: mm).

a)

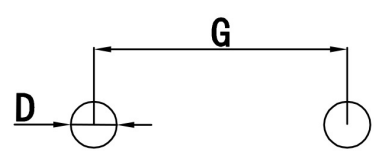

c)

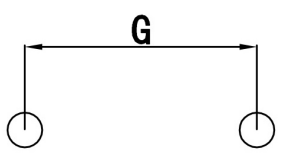

$\stackrel{\text { D }}{-} \mathrm{O}-$ b)
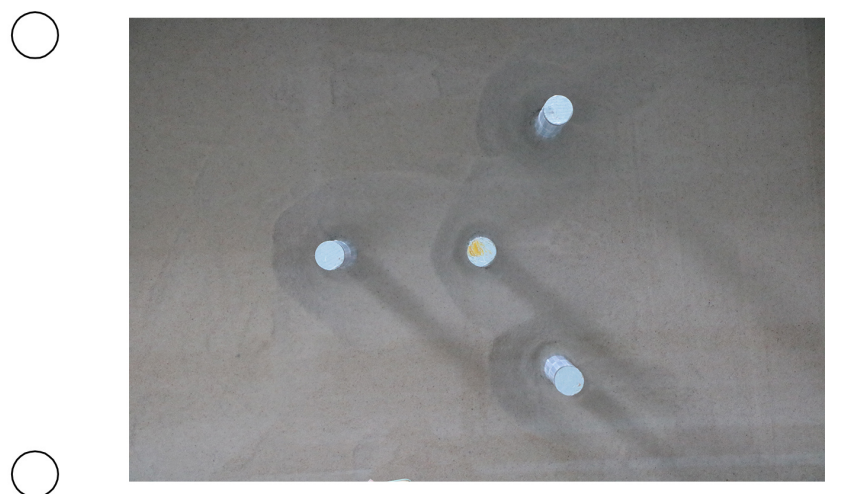

d)

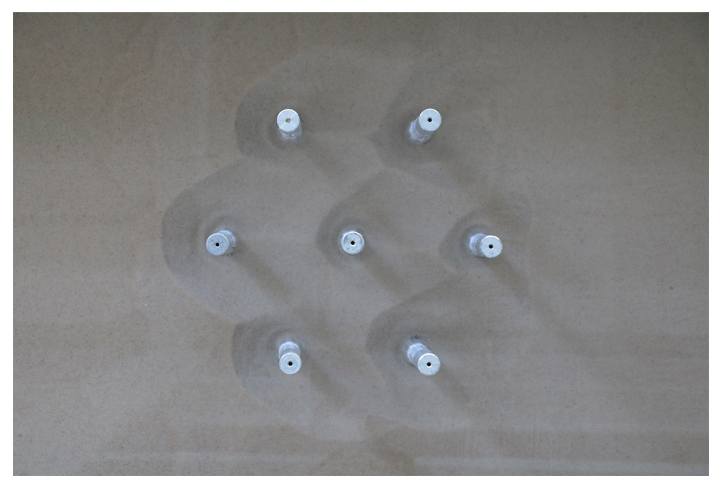

Figure 4. Sketches of the pile group models: (a) Top-view of triangular arrays of circular cylinders (TACC); (b) Photograph of TACC (c) Top-view of hexagonal arrays of circular cylinders (HACC); (d) Photograph of HACC. 


\subsection{Experimental Procedure}

Before conducting each experiment, the sediment bed is leveled and parallel to the bottom slope of the flume. The water is carefully filled to prevent scouring around the models. When the water depth is close to the desired value; the inlet flow discharge is gradually increased to the target value. Once the steady flow reaches the target flow condition, the scour test starts, and this moment is defined as the initial scour time.

The meter tape is stuck on the legs of each model. The measurement positions around each leg are selected as the azimuth of $0^{\circ}, 90^{\circ}, 180^{\circ}$ and $270^{\circ}$ in the clockwise direction. As the center pile in tripod and hexapod model is the non-insert root; the scour depth under center pile is measured with the help of a ruler. An endoscope is used to take photos of the meter tape, and the scour depth is obtained by analyzing the images. The accuracy of scour depth is $1 \mathrm{~mm}$. All the test conditions and results are shown in Table 2. The $D$ is the leg's diameter of each model, $S_{\text {end }}$ is the maximum scour depth at the end of each test.

Table 2. Experimental conditions and results.

\begin{tabular}{cccccccc}
\hline No. & Model & $\mathbf{t}(\mathbf{m i n})$ & $\mathbf{U} / \mathbf{U}_{\boldsymbol{c}}$ & $\left.\boldsymbol{\alpha} \mathbf{(}^{\circ}\right)$ & $\mathbf{D}(\mathbf{m m})$ & $\mathbf{G} / \mathbf{D}$ & $S_{\text {end }} / \mathbf{D}$ \\
\hline 1 & TACC & 1800 & 0.93 & 0 & 40 & 5.50 & 1.53 \\
2 & TACC & 1800 & 0.74 & 60 & 40 & 5.50 & 1.40 \\
3 & TACC & 1800 & 0.93 & 60 & 40 & 5.50 & 1.73 \\
4 & TACC & 1800 & 0.93 & 30 & 40 & 5.50 & 1.64 \\
5 & HACC & 1800 & 0.74 & 0 & 30 & 6.67 & 0.90 \\
6 & HACC & 1800 & 0.93 & 0 & 30 & 6.67 & 1.77 \\
7 & HACC & 1800 & 0.93 & 30 & 30 & 6.67 & 2.10 \\
8 & HACC & 1800 & 0.93 & 15 & 30 & 6.67 & 2.43 \\
9 & Hexapod & 1800 & 0.74 & 0 & 30 & 6.67 & 0.87 \\
10 & Hexapod & 1800 & 0.93 & 0 & 30 & 6.67 & 2.23 \\
11 & Hexapod & 1800 & 0.93 & 30 & 30 & 6.67 & 2.28 \\
12 & Hexapod & 1800 & 0.93 & 15 & 30 & 6.67 & 2.80 \\
13 & Tripod & 1200 & 0.74 & 0 & 40 & 5.50 & 1.39 \\
14 & Tripod & 1800 & 0.93 & 0 & 40 & 5.50 & 2.46 \\
15 & Tripod & 1800 & 0.74 & 60 & 40 & 5.50 & 1.85 \\
16 & Tripod & 1800 & 0.93 & 60 & 40 & 5.50 & 2.38 \\
17 & Tripod & 1200 & 0.74 & 30 & 40 & 5.50 & 1.48 \\
18 & Tripod & 1800 & 0.93 & 30 & 40 & 5.50 & 2.50 \\
19 & Monopile & 2820 & 0.93 & - & 80 & - & 1.13 \\
20 & Monopile & 2820 & 0.74 & - & 80 & - & 0.69 \\
\hline
\end{tabular}

\section{Results and Discussions}

\subsection{Effective Diameter for Tripod and Hexapod Foundations}

For pile groups, the effective diameter is used to represent such foundations' characteristic geometry [19]. An approach to calculate the effective diameter of a pile group has been given by Arneson et al. [14], and it could be expressed as

$$
D_{e}=K_{s p} D_{\text {proj }}
$$

where $K_{s p}$ is the coefficient for pile spacing and $D_{\text {proj }}$ is the projected width of the pile group. The $K_{s p}$ is calculated by

$$
K_{s p}=1-\frac{4}{3}\left[1-\frac{D}{D_{\text {proj }}}\right]\left[1-\left(\frac{G}{D}\right)^{-0.6}\right],
$$

in which $D$ is the leg's diameter in pile groups, $G$ is the minimum center spacing between piles.

For the pile group, the projected width is the sum of the projections of the non-overlapping widths of the individual piles. The projected width of the HACC model is illustrated in Figure 5. 


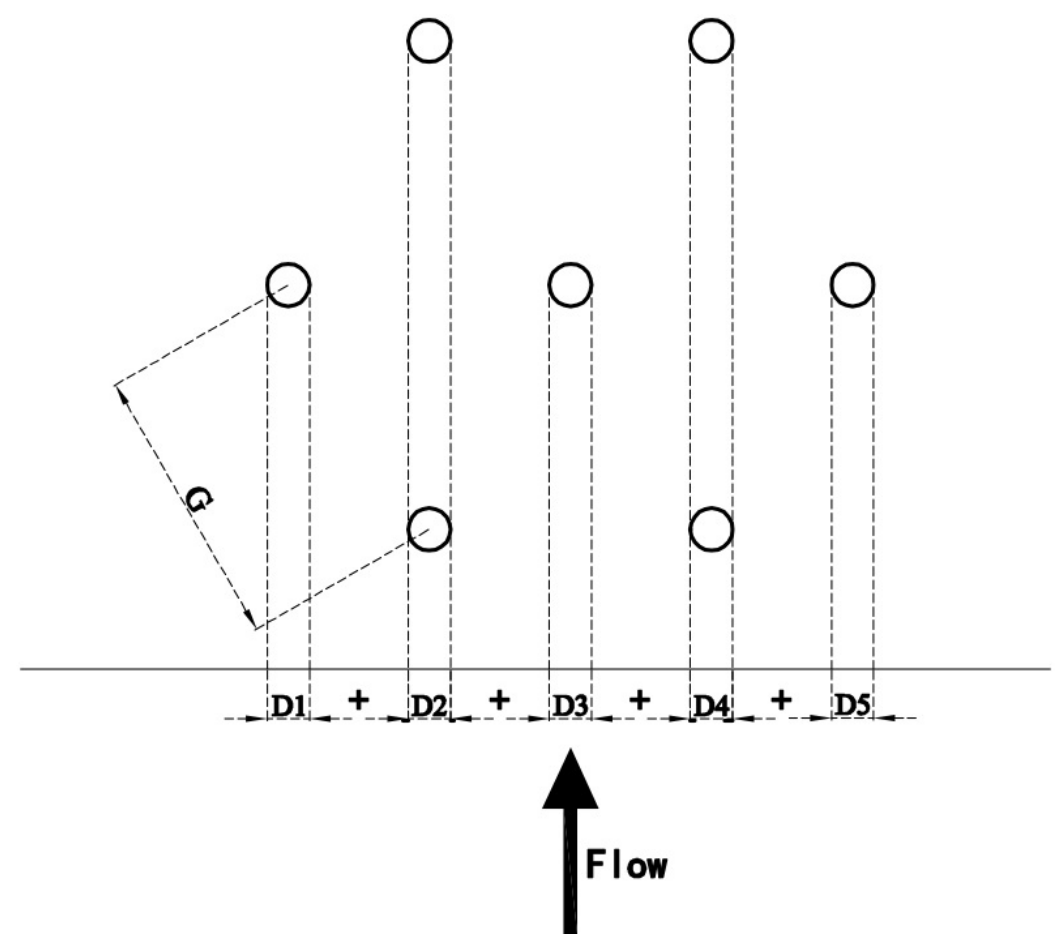

Figure 5. Diagram illustrating the effective diameter $\left(\mathrm{D}_{e}\right)$ of pile group from Arneson et al. [14].

Then the projected width of pile group could be expressed as

$$
D_{\text {proj }}=D 1+D 2+\cdots+D 5
$$

As the tripod and hexapod foundations are in more complex shapes, the effective diameter cannot be applied directly. In this study, for the tripod and hexapod models, the projected width is the projected area divided by the water depth. The projected area is the sum of projections of the non-overlapping areas of the individual elements. The projected width of such models could be expressed as

$$
D_{\text {proj }}=\frac{A_{\text {proj }}}{h}
$$

where $A_{\text {proj }}$ is the projected area, and $h$ is the water depth. For example, the $A_{\text {proj }}$ of the hexapod model is shown in Figure 6.

Similarly as for the pile groups, the $K_{s p}$ for tripod and hexapod models is calculated by Equation (3). The $D$ in Equation (3) is taken the value of the leg's diameter. The center piles in both tripod and hexapod models are non-insert roots, yet they significantly influence on the flow around each model. Therefore, $G$ is the minimum value of spacing between the legs and between the center pile and the legs. Then the effective diameter for the tripod and hexapod foundations could be calculated through Equation (2).

Table 3 shows the averaged value of maximum scour depth at the end of each test normalized by the original diameter $\left(S_{\text {end }} / D\right)_{\text {ave }}$ and the effective diameter $\left(S_{\text {end }} / D_{e}\right)_{\text {ave }}$ for complex foundation models (tripod and hexapod model) and pile group models (TACC and HACC models).

The $\left(S_{\text {end }} / D\right)_{\text {ave }}$ of the complex foundation model is $31 \%$ and $26 \%$ larger than that of the pile group model for $U=0.93 U_{c}$ and $U=0.74 U_{c}$, respectively. Meanwhile, the $\left(S_{\text {end }} / D_{e}\right)_{\text {ave }}$ is only $7 \%$ larger and $9 \%$ less than that of the pile group model for $U=0.93 U_{c}$ and $U=0.74 U_{c}$, respectively. Therefore, it is reasonable to use the effective diameter to represent the characteristic geometry of the tripod and hexapod models. 


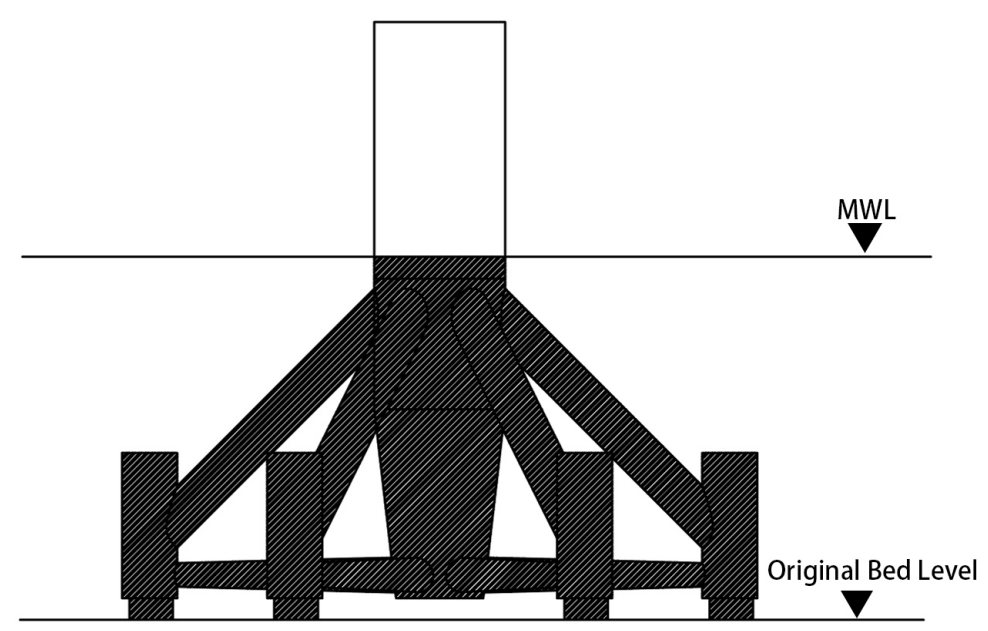

Figure 6. Diagram illustrating the projected area of hexapod model.

Table 3. Averaged maximum scour depth for each type of foundation models.

\begin{tabular}{cccc}
\hline Model & $\mathrm{U}$ & $\left(S_{\text {end }} / D\right)_{\text {ave }}$ & $\left(S_{\text {end }} / D_{\boldsymbol{e}}\right)_{\text {ave }}$ \\
\hline \multirow{2}{*}{ Complex Foundation } & $0.93 U_{c}$ & 2.44 & 1.49 \\
& $0.74 U_{c}$ & 1.45 & 0.84 \\
\hline \multirow{2}{*}{ Pile Group } & $0.93 U_{c}$ & 1.86 & 1.39 \\
& $0.74 U_{c}$ & 1.15 & 0.92 \\
\hline
\end{tabular}

\subsection{Equilibrium Scour Depth}

\subsubsection{Criterion for Equilibrium}

Time is an important factor for the scouring process, and it has been discussed by many researchers [23-26]. Regarding the equilibrium scour depth under steady current, different criteria can be found in previous literatures, which could result in different equilibrium time of scour. For the small-scale laboratory experiments, Melville and Chiew [4] suggested that the time of equilibrium condition should satisfy the condition that the rate of increase of scour does not exceed a specific percentage of the pier diameter in the succeeding 24-h period, that is,

$$
\frac{d S}{d t} \leq \frac{n D}{24 \mathrm{~h}^{\prime}}
$$

where $S$ is the scour depth, $t$ is the time, $D$ is the diameter of the pier, $n$ is the specific percentage (here $n=5 \%$ ) of the pier diameter. Grimaldi [26] suggested a more restrictive criterion that $n$ in Equation (6) is $1.67 \%$.

Figure 7 shows the temporal evolution and development rate per hour of normalized scour depth $S / D$ for hexagonal arrays of circular cylinders (HACC).

According to Equation (6), the scour around the HACC model still increases slowly with time and does not reach its equilibrium. Therefore, in the present study, the time factor $K_{t}$ is used to account for the effect of time on the scour depth development. $K_{t}$ is defined as the fraction of equilibrium scour depth at time $t$, that is, $K_{t}(t)=S(t) / S_{e q}$. Here $S(t)$ is the scour depth at time $t$, and $S_{e q}$ is the equilibrium scour depth. According to Baghbadorani et al. [27], the value of $S_{e q}$ can be achieved by the following methods: the value of $K_{t}$ for each case is calculated at the end of each test, that is, $K_{t}\left(t_{\text {end }}\right)$. Then the equilibrium scour depth could be derived through $S_{\text {eq }}=S_{\text {end }} / K_{t}\left(t_{\text {end }}\right)$. 


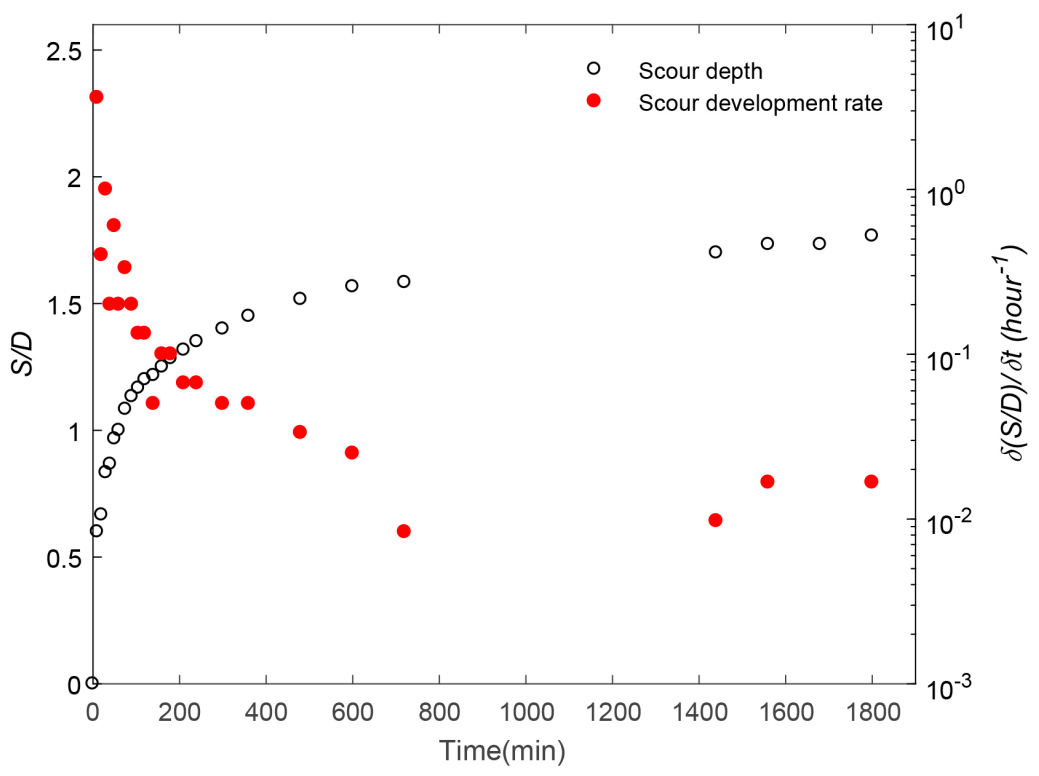

Figure 7. Temporal evolution and development rate per hour of the maximum scour depth for hexagonal arrays of circular cylinders (HACC) at $U=0.93 U_{c}$.

\subsubsection{Extrapolated Equilibrium Scour Depth}

In this study, three $K_{t}$ equations are selected and shown in Table 4 , which are from Melville and Chiew [4], Kothyari et al. [28] and Lança et al. [22], respectively. All the $K_{t}$ equations are proposed based on the results of the monopile. Since the mechanism of scouring at pile groups is more complicated, the $K_{t}$ equations derived for the single pier cannot be directly applied to the pile group and complex foundation models. According to Baghbadorani et al. [27], the $K_{t}$ equations are modified for use in pile groups by substituting $D=D_{e}$ where $D_{e}$ is the effective diameter of the pile group.

Table 4. Summary of selected equations for time factor, $K_{t}$.

\begin{tabular}{cc}
\hline & $K_{t}$ Equation \\
\hline Melville and Chiew [4] & $K_{t}=\exp \left(-0.03\left|\frac{U_{c}}{U} \ln \left(\frac{t}{t_{1}}\right)\right|^{1.6}\right)$ \\
$t_{1}=48.26 \frac{D_{e}}{U}\left(\frac{U}{U_{c}}-0.4\right)$ for $\frac{h}{D_{e}}>6$ \\
$t_{1}=30.89 \frac{D_{e}}{U}\left(\frac{U}{U_{c}}-0.4\right)\left(\frac{h}{D_{e}}\right)^{0.25}$ for $\frac{h}{D_{e}} \leq 6$ \\
\hline Kothyari et al. [28] \\
$K_{t}=\frac{1}{4.8 F_{d}^{1 / 5}} \log \left(\frac{t}{t_{1}}\right)$ \\
\hline Lança et al. [22] \\
$F_{d}=\frac{U}{\left(1.65 g d_{50}\right)^{1 / 2}}, t_{1}=\frac{h^{1 / 3} D_{e}^{2 / 3}}{\sigma_{g}^{1 / 3}\left(1.65 g d_{50}\right)^{1 / 2}}$ \\
$K_{t}=1-\exp \left(-a_{1}\left(U t / D_{e}\right)^{a_{2}}\right)$ \\
$a_{1}=1.22\left(D_{e} / d_{50}\right)^{-0.764}, a_{2}=0.09\left(D_{e} / d_{50}\right)^{0.244}$ \\
\hline
\end{tabular}

A comparison of the selected $K_{t}$ equations has been made through mean absolute percentage error (MAPE), root mean square error (RMSE), and the correlation coefficient (CC) based on the measured data and calculated value, and they are shown in Table 5. Figure 8 represents the measured data and fitted curves of scour temporal evolution for the HACC model. 
Table 5. Comparison of statistical indices based on results from different $K_{t}$ equations.

\begin{tabular}{cccc}
\hline & Melville and Chiew [4] & Kothyari et al. [28] & Lança et al. [22] \\
\hline MAPE & $12.96 \%$ & $15.38 \%$ & $8.22 \%$ \\
RMSE & 0.21 & 0.23 & 0.12 \\
CC & 0.96 & 0.95 & 0.98 \\
\hline
\end{tabular}

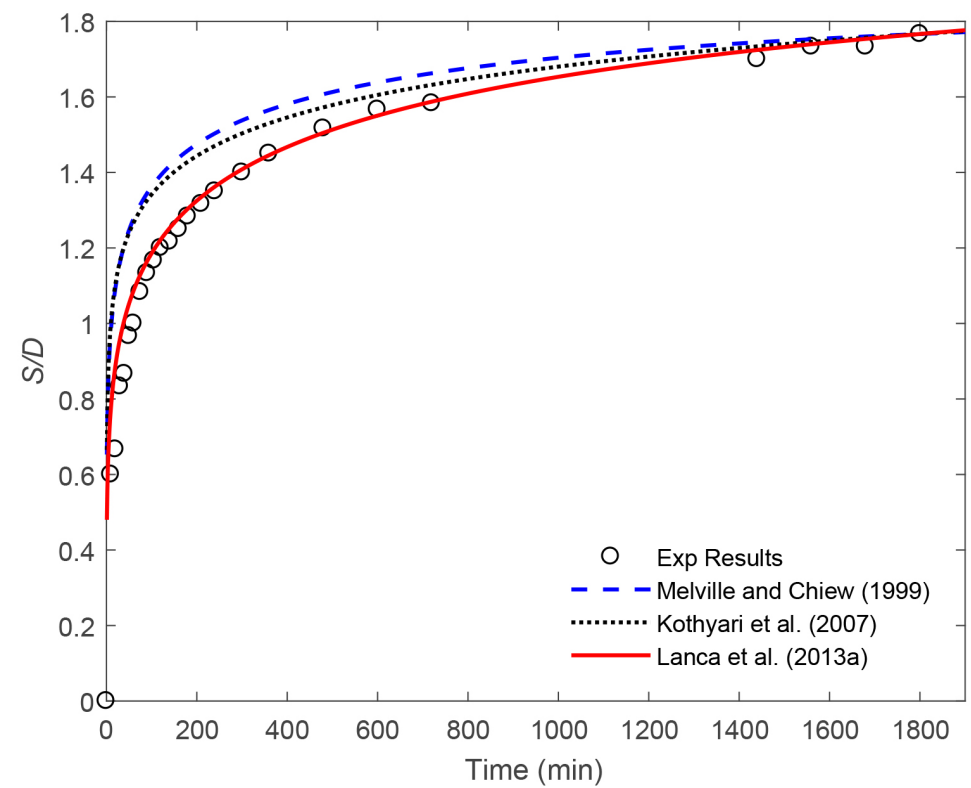

Figure 8. Measured temporal evolution of the maximum scour depth for HACC model compared to time factor equations.

From Table 5 and Figure 8, as the $K_{t}$ equation from Lança et al. [22] agrees better with the experimental data, it is used for extrapolation of scour data for all the models in this study. The equilibrium scour depth $S_{e q}$ through extrapolation are shown in Table 6.

Table 6. Equilibrium scour depth based on $K_{t}$ equation from Lança et al. [22]. ( $S_{\text {end }}$ : maximum scour depth at the end of each test; $S_{e q}$ : equilibrium scour depth of each test).

\begin{tabular}{cccccc}
\hline No. & $\mathbf{S}_{\text {end }} / \mathrm{D}$ & $\mathrm{S}_{\boldsymbol{e q}} / \mathrm{D}$ & No. & $\mathrm{S}_{\text {end }} / \mathrm{D}$ & $\mathrm{S}_{\boldsymbol{e q}} / \mathrm{D}$ \\
\hline 1 & 1.53 & 2.02 & 10 & 2.23 & 2.91 \\
2 & 1.40 & 1.91 & 11 & 2.28 & 3.00 \\
3 & 1.73 & 2.28 & 12 & 2.80 & 3.69 \\
4 & 1.64 & 2.17 & 13 & 1.39 & 2.06 \\
5 & 0.90 & 1.19 & 14 & 2.46 & 3.33 \\
6 & 1.77 & 2.27 & 15 & 1.85 & 2.58 \\
7 & 2.10 & 2.73 & 16 & 2.38 & 3.21 \\
8 & 2.43 & 3.15 & 17 & 1.48 & 2.17 \\
9 & 0.87 & 1.16 & 18 & 2.50 & 3.36 \\
\hline
\end{tabular}

\subsection{Performance of Existing Scour Depth Predictors}

Various researchers have attempted to develop prediction methods of the equilibrium scour depth for pile groups. According to Melville and Coleman [29], the equilibrium scour depth $S_{e q}$ of pile groups with uniform sediment under steady current condition could be expressed as

$$
\frac{S_{e q}}{D_{e}}=C K_{h} K_{d} K_{I},
$$


where $S_{e q}$ is the equilibrium scour depth, $D_{e}$ is the effective diameter of the pile group, $C$ is the constant coefficient, $K_{h}$ is the coefficient of water depth, $K_{d}$ is the coefficient of sediment size, and $K_{I}$ is the coefficient of flow velocity. In this work, three widely used equilibrium scour depth predictors are chosen, which are HEC-18 method [14], the Auckland method [15] and the FDOT method [19]. The HEC-18 (Hydraulic Engineering Circular No. 18) has been evolving progressively over the years, and it is currently a recommended method by the FHWA (Federal Highway Administration) [14]. The FDOT (Florida Department of Transportation) method and the Auckland method are also widely used to predict the scour depth for pile-supported foundations. All the methods are designed for clear-water condition. The factors of three selected methods are shown in Table 7.

Table 7. Summary of selected equations for equilibrium scour depth estimation around pile groups.

\begin{tabular}{cccc}
\hline & HEC-18 & Auckland & FDOT \\
\hline$C$ & 2.2 & 1 & 2.5 \\
\hline & & 2.4 for $\frac{D_{e}}{h}<0.7$ & \\
$K_{h}$ & $\left(\frac{h}{D_{e}}\right)^{0.35}$ & $\begin{array}{r}2 \sqrt{\frac{h}{D_{e}}} \text { for } 0.7 \leq \frac{D_{e}}{h} \geq 5 \\
4.5 \frac{h}{D_{e}} \text { for } \frac{D_{e}}{h}>5\end{array}$ & $\tanh \left[\left(\frac{h}{D_{e}}\right)^{0.4}\right]$ \\
\hline & & $0.57 \log \left(2.24 \frac{D_{e}}{d_{50}}\right)$ for $\frac{D_{e}}{d_{50}} \leq 25$ & $\frac{D_{e} / d_{50}}{0.4\left(D_{e} / d_{50}\right)^{1.2}+10.6\left(D_{e} / d_{50}\right)^{-0.13}}$ \\
$K_{d}$ & - & 1 for $\frac{D_{e}}{d_{50}}>25$ & $1-1.75\left[\ln \left(\frac{U}{U_{c}}\right)\right]^{2}$ \\
\hline$K_{I}$ & $\left(\frac{U}{\sqrt{g h}}\right)^{0.43}$ & $\frac{U}{U_{c}}$ &
\end{tabular}

\subsubsection{Performance of Selected Methods on Pile Groups}

Even though the selected scour depth predictors are all designed for pile groups, they have not fully verified by experimental results. Thus, their systematic assessment against data based on different conditions is still necessary [30]. The performance of existing methods is assessed using the following parameters: mean absolute percentage error (MAPE), root-mean-square error (RMSE), correlation coefficient (CC), and discrepancy ratio (DR). For MAPE and RMSE, a value of zeros indicates an excellent performance while large positive values are undesirable; for CC, a value of 1 is desirable, and small values near 0 are undesirable. Discrepancy ratio (DR) of 1 shows an unbiased model, whereas DR $<1$ shows underestimation, and DR $>1$ shows overestimation behavior.

The clear-water scour around hexagonal arrays of circular cylinders (HACC) in steady flow conditions has been investigated by Yagci et al. [31] through laboratory experiments, including four gaps between adjacent piles and three incident flow angles. The statistical results based on both present experimental results and the data from Yagci et al. [31] for each method are shown in Table 8.

Table 8. Comparison of statistical indices based on results of pile groups.

\begin{tabular}{cccc}
\hline & HEC-18 & Auckland & FDOT \\
\hline MAPE & $11.61 \%$ & $35.80 \%$ & $29.76 \%$ \\
RMSE & 0.41 & 1.54 & 1.05 \\
CC & 0.94 & 0.93 & 0.94 \\
DR & 1.04 & 1.36 & 1.30 \\
\hline
\end{tabular}

From Table 8, the best method with the smallest MAPE and RMSE is the HEC-18 method, while the poorest method with the largest MAPE and RMSE is the Auckland method (MAPE $=35.80 \%$ and RMSE $=1.54$ ). In terms of the correlation coefficient, the HEC-18 method and FDOT method show the same performance with CC $=0.94$, and CC of the Auckland method is 0.93. In terms of DR, all three methods suffer from overestimation with DR $>1$. 


\subsubsection{Performance of Selected Methods on Both Pile Groups and Complex Foundations}

While the selected methods exhibit variable performance on predicting the equilibrium scour depth on the pile groups, all the methods present acceptable estimations. The performance of these methods on the complex foundations (tripod and hexapod models) is still unknown. Yuan et al. [18] investigated the scour around a tripod foundation, including three alignment angles and two flow velocities. A comparison through the statistical indices is made here to evaluate the performance of the selected methods on both pile groups and complex foundations. The results are obtained based on the present data as well as the published data from Yuan et al. [18], and they are shown in Table 9.

Table 9. Comparison of statistical indices based on results of both pile groups and complex foundations.

\begin{tabular}{cccc}
\hline & HEC-18 & Auckland & FDOT \\
\hline MAPE & $26.52 \%$ & $44.21 \%$ & $29.89 \%$ \\
RMSE & 0.58 & 1.29 & 0.91 \\
CC & 0.89 & 0.90 & 0.94 \\
DR & 1.18 & 1.44 & 1.25 \\
Deviation 30\% & $86 \%$ & $47 \%$ & $61 \%$ \\
\hline
\end{tabular}

In terms of MAPE and RMSE, the predictions from HEC-18 show the best agreement with the observed data, and the Auckland method shows the poorest performance. In terms of the correlation coefficient, all the methods show similar performance, while the best method is FDOT with CC $=0.94$.

Figure 9 compares the equilibrium scour depth of the present experimental data and those computed with the mentioned methods. The perfect agreement line and lines corresponding to $\pm 30 \%$ and $\pm 50 \%$ deviations are included. The number of predictions within and outside $\pm 30 \%$ error lines is also made to evaluate the performance of each method. From this figure, the HEC-18 method has the most number of predictions that fall within $\pm 30 \%$ error lines, with $86 \%$ of predictions within the two bounds. The poorest method is the Auckland method, only $44 \%$ of predictions between the two bounds. Generally, the design of offshore foundations is preferred conservative for practical engineering. Even though all the methods provide conservative results in terms of DR, 53\% of the estimation based on HEC-18 are under-prediction. In contrast, only 0 and $8 \%$ of predictions calculated from the Auckland and FDOT methods are underestimations, respectively. In addition, 56\% of estimations based on the FDOT method lies between $+30 \%$ error line and perfect agreement line, while only $33 \%$ of estimation calculated from the HEC-18 method lies between the two bounds. By considering the other error analysis from Table 9, the FDOT method is recommended on estimating equilibrium scour depth for pile groups and complex foundations in practical engineering.

It should be pointed out that the deviation between the experimental results and the estimations is larger than $50 \%$ in the circled part of Figure 9. These experimental results are obtained at small flow velocities (present study: $U=0.74 U_{c}$; Yuan et al. [18]: $U=0.50 U_{c}$ ). A similar observation could be found in the study conducted by Ataie-Ashtiani et al. [32]. This may be because the pile group and complex foundations have different flow velocities for the scour initiation than monopiles, leading to a larger deviation at small flow velocities. The effect of flow velocity should be verified with more studies in the future. 
a)

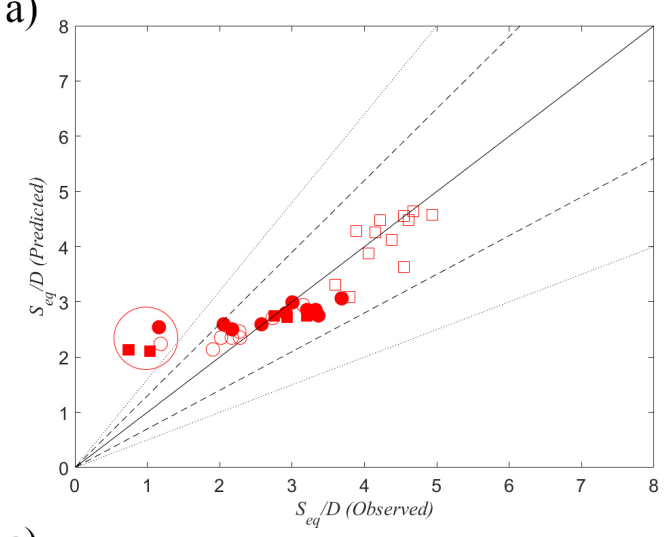

c)

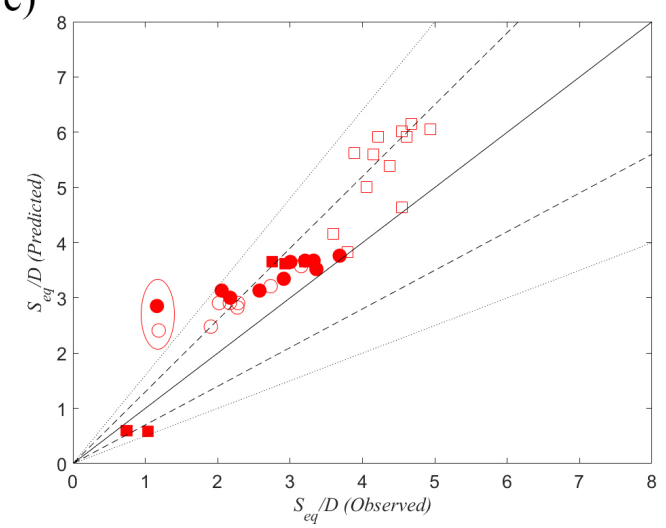

b)

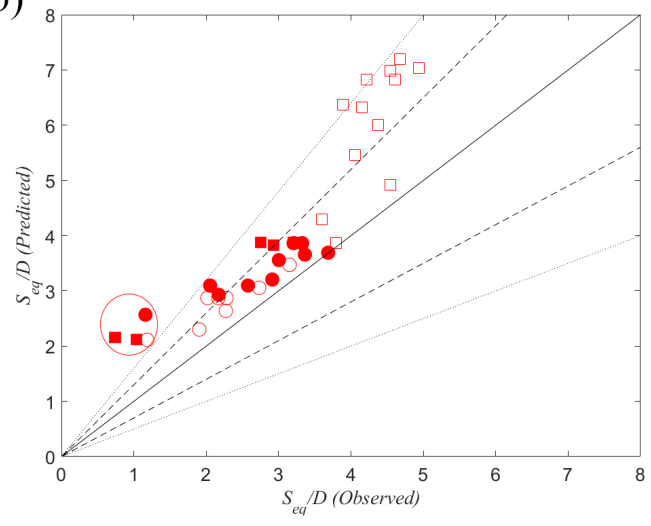

Figure 9. Comparison of observed and predicted scour depth based on effective diameter. (a) the Hydraulic Engineering Circular No. 18 (HEC-18) method; (b) the Auckland method; (c) the FDOT method.

\section{Conclusions}

The clear-water scour around tripod and hexapod foundations under steady current conditions is investigated experimentally in this study. Two flow velocities and five pile-supported foundation models are considered. The equilibrium scour depth is derived through extrapolation. Three widely used methods for estimation of equilibrium scour depth are compared through both the present experimental results and the previously published data. The main conclusions are summarized as follows:

(1) An approach to calculate the effective diameter for the tripod and hexapod models is proposed in the present study. Essentially the projected width of such models is calculated by projected area divided by the water depth.

(2) The equilibrium scour depth is obtained through extrapolation from $K_{t}$ equation of Lança et al. (2013), as it shows the best agreement with the measured results among three selected equations.

(3) The performance of three equilibrium scour-depth prediction equations -namely, the HEC-18 method (Arneson et al., 2012), the Auckland method (Coleman, 2005) and the FDOT method (Sheppard, 2005)—is assessed based on both the present results and published data. Both pile groups and complex foundation models are included. As the FDOT method provides relatively accurate and conservative predictions, for practical engineering purposes, the FDOT method is recommended for pile groups and complex foundations.

It should be noted that the gap distances between the beams and the sediment bed in the present models and the models conducted by Yuan et al. (2017) are small. The beams have significant influences on the near-bed flow. Therefore, the effective diameter is calculated by considering the beam's projected area in the present study. Further studies should check if the approach can be applied to foundations 
with different gap distances. Besides, the present results are obtained from laboratory experiments. Therefore, they are subject to certain limitations, such as the scaling effect and only non-cohesive uniform sediment. It will be useful to check if they can be applied to the practical structures in reality.

Author Contributions: This paper was the result of collaborative teamwork. Experiment and data analysis, X.N.; Writing-original draft, X.N.; Writing_review and editing, L.X.; Supervision, L.X. All authors have read and agreed to the published version of the manuscript.

Funding: This research was funded by Ministry of Science and Technology of the People's Republic of China, grant number No.2019YFB1503703.

Acknowledgments: This work was supported by the National Key Research and Development Program of China [No.2019YFB1503703].

Conflicts of Interest: The authors declare no conflict of interest.

\section{References}

1. Ben Meftah, M.; De Serio, F.; De Padova, D.; Mossa, M. Hydrodynamic Structure with Scour Hole Downstream of Bed Sills. Water 2020, 12, 186. [CrossRef]

2. Ben Meftah, M.; Mossa, M. New approach to predicting local scour downstream of grade-control structure. J. Hydraul. Eng. 2020, 146, 04019058. [CrossRef]

3. Raudkivi, A.J.; Ettema, R. Clear-water scour at cylindrical piers. J. Hydraul. Eng. 1983, 109, 338-350. [CrossRef]

4. Melville, B.W.; Chiew, Y.M. Time scale for local scour at bridge piers. J. Hydraul. Eng. 1999, 125, 59-65. [CrossRef]

5. Sumer, B.M.; Fredsøe, J. The Mechanics of Scour in the Marine Environment; World Scientific Publishing Company: Singapore, 2002; Volume 17.

6. Roulund, A.; Sumer, B.M.; Fredsøe, J.; Michelsen, J. Numerical and experimental investigation of flow and scour around a circular pile. J. Fluid Mech. 2005, 534, 351-401. [CrossRef]

7. Qi, W.; Gao, F. Equilibrium scour depth at offshore monopile foundation in combined waves and current. Sci. China Technol. Sci. 2014, 57, 1030-1039. [CrossRef]

8. Qi, W.G.; Gao, F.P. Local Scour around a Monopile Foundation for Offshore Wind Turbines and Scour Effects on Structural Responses. In Geotechnical Engineering-Advances in Soil Mechanics and Foundation Engineering; IntechOpen: London, UK, 2019.

9. Liang, B.; Du, S.; Pan, X.; Zhang, L. Local Scour for Vertical Piles in Steady Currents: Review of Mechanisms, Influencing Factors and Empirical Equations. J. Mar. Sci. Eng. 2020, 8, 4. [CrossRef]

10. Sumer, B.M.; Fredsøe, J.; Bundgaard, K. Global and local scour at pile groups. In The Fifteenth International Offshore and Polar Engineering Conference, Seoul, Korea, 19-24 June 2005; International Society of Offshore and Polar Engineers: Seoul, Korea, 2005.

11. Amini, A.; Melville, B.W.; Ali, T.M.; Ghazali, A.H. Clear-water local scour around pile groups in shallow-water flow. J. Hydraul. Eng. 2011, 138, 177-185. [CrossRef]

12. Liang, F.; Wang, C.; Huang, M.; Wang, Y. Experimental observations and evaluations of formulae for local scour at pile groups in steady currents. Mar. Georesources Geotechnol. 2017, 35, 245-255. [CrossRef]

13. Qi, W.G.; Li, Y.X.; Xu, K.; Gao, F.P. Physical modelling of local scour at twin piles under combined waves and current. Coast. Eng. 2019, 143, 63-75. [CrossRef]

14. Arneson, L.; Zevenbergen, L.; Lagasse, P.; Clopper, P. Evaluating Scour at Bridges, 4th ed.; Hydraulic Engineering Circular No. 18 (HEC-18); Federal Highway Administration: Washington, DC, USA, 2012.

15. Coleman, S.E. Clearwater local scour at complex piers. J. Hydraul. Eng. 2005, 131, 330-334. [CrossRef]

16. Stahlmann, A.; Schlurmann, T. Physical modeling of scour around tripod foundation structures for offshore wind energy converters. In Proceedings of the Coastal Engineering Conference (2010); American Society of Civil Engineers: Reston, VA, USA, 2010.

17. Stahlmann, A.; Schlurmann, T. Investigations on scour development at tripod foundations for offshore wind turbines: modeling and application. Coast. Eng. Proc. 2012, 1, 90. [CrossRef]

18. Yuan, C.; Melville, B.W.; Adams, K.N. Scour at wind turbine tripod foundation under steady flow. Ocean. Eng. 2017, 141, 277-282. [CrossRef] 
19. Sheppard, D.M.; Renna, R. Bridge Scour Manual; Technical Report; Florida Department of Transportation: Tallahassee, FL, USA, 2005.

20. Hongwu, T.; Wang, H.; Liang, D.; Lv, S.; Yan, L. Incipient motion of sediment in the presence of emergent rigid vegetation. J. Hydrol. Environ. Res. 2013, 7, 202-208. [CrossRef]

21. Alabi, P.D. Time Development of Local Scour at a Bridge Pier Fitted with a Collar. Ph.D. Thesis, University of Saskatchewan, Saskatoon, SK, Canada, 2006.

22. Lança, R.; Fael, C.; Maia, R.; Pêgo, J.P.; Cardoso, A.H. Clear-water scour at pile groups. J. Hydraul. Eng. 2013, 139, 1089-1098. [CrossRef]

23. Sumer, B.; Christiansen, N.; Fredsoe, J. Time scale of scour around a vertical pile. In The Second International Offshore and Polar Engineering Conference; International Society of Offshore and Polar Engineers: San Francisco, CA, USA, 1992.

24. Cardoso, A.; Bettess, R. Effects of time and channel geometry on scour at bridge abutments. J. Hydraul. Eng. 1999, 125, 388-399. [CrossRef]

25. Coleman, S.E.; Lauchlan, C.S.; Melville, B.W. Clear-water scour development at bridge abutments. J. Hydraul. Res. 2003, 41, 521-531. [CrossRef]

26. Grimaldi, C. Non-Conventional Countermeasures Against Local Scouring at Bridge Piers. Ph.D. Thesis, Hydraulic Engineering for Environment and Territory, University of Calabria, Rende, Italy, 2005.

27. Baghbadorani, D.A.; Beheshti, A.A.; Ataie-Ashtiani, B. Scour hole depth prediction around pile groups: Review, comparison of existing methods, and proposition of a new approach. Nat. Hazards 2017, 88, 977-1001. [CrossRef]

28. Kothyari, U.C.; Hager, W.H.; Oliveto, G. Generalized approach for clear-water scour at bridge foundation elements. J. Hydraul. Eng. 2007, 133, 1229-1240. [CrossRef]

29. Melville, B.W.; Coleman, S.E. Bridge Scour; Water Resources Publication, LLC: Littleton, CO, USA, 2000.

30. Moreno, M.; Birjukova, O.; Grimaldi, C.; Gaudio, R.; Cardoso, A.H. Experimental study on local scouring at pile-supported piers. Acta Geophys. 2017, 65, 411-421. [CrossRef]

31. Yagci, O.; Yildirim, I.; Celik, M.F.; Kitsikoudis, V.; Duran, Z.; Kirca, V.O. Clear water scour around a finite array of cylinders. Appl. Ocean. Res. 2017, 68, 114-129. [CrossRef]

32. Ataie-Ashtiani, B.; Baratian-Ghorghi, Z.; Beheshti, A. Experimental investigation of clear-water local scour of compound piers. J. Hydraul. Eng. 2010, 136, 343-351. [CrossRef]

Publisher's Note: MDPI stays neutral with regard to jurisdictional claims in published maps and institutional affiliations.

(C) 2020 by the authors. Licensee MDPI, Basel, Switzerland. This article is an open access article distributed under the terms and conditions of the Creative Commons Attribution (CC BY) license (http://creativecommons.org/licenses/by/4.0/). 